\title{
The Aesthetic of Mantra as Medical Treatment in Malay-Riau
}

\author{
Syafrial, Hadi Rumadi, Oki Rasdana \\ Language and Literature Education, Riau University \\ syafrialpbsiunri@gmail.com, hadirumadipspbsi@gmail.com, oki.rasdana@lecturer.unri.ac.id
}

\begin{abstract}
The background of the research described and discussed the empowerment of the aesthetics of sounds and words of mantra in the treatment of Malay Riau society which is collected in The Book of Mantra. The formulation of this research is how is the aesthetic utilization of mantra of medical treatment of Malay Riau society. The purpose of this article is to describe the aesthetics of sounds and words in the Malay community treatment spell. This type of research is qualitative. The method of this research is Ethnography method. The Data collection techniques used in this research are observation, interview and document study. The Data analysis technique is a technique revealed by Miles is data reduction, data presentation, and withdrawal of the final conclusion. The result of this study is the aesthetics of the initial sound of sixty three, the central sound is one hundred and one, and the final sound is seventy five and the initial word is forty eight, the middle word is fifty one, and the final word is twenty seven. The repetition of sounds and words in the mantra sounds similar or rhythmic, beautiful tones that are part of a literary aesthetic. This beauty is a form of affirmation and giving of emotion from speakers through aesthetic mantras conveyed through the aesthetic sounds and words that exist in each mantra.
\end{abstract}

Keywords-Aesthetic; Mantra; Treatment

\section{INTRODUCTION}

Two important elements that build literary works and distinguish the work of literature with other forms of work that are the element of aesthetics and ethics. Both of these elements attract each other or dominate each other in literary works. Sometimes the aesthetic element dominates a literary work and is sometimes also the dominating ethical element. If the literary works have a balance of these two elements, the quality of the literary works can be judged perfect.

Mantra, as the oldest literary work on the genre of poetry is always enjoyed by aesthetic elements. The language in the mantra has a distinctive word art, the words selected the rhythm, the contents are considered deeply (Agus, Bakhtaruddin,Ismail,2013, p. 2). As has been well established, a language - centered approach is necessary for the study of literature since all literature exists only in and through language (Dita, 2010, p. 169). The power of mantra is viewed from the literary point as if it lies in its aesthetic power while the ethical realm is part of the mystery and rarely touched by the literary connoisseur. This is due to the purpose of the person getting the spell. In principle, the spreading of mantra verbally from one person to another personally always consider the effect that can be caused by the mantra. People put aside the meaning of the mantra lines while the sustra lovers can only grasp the beauty of the spell when pronounced its speaker. As a type of literature, the mantra becomes unique and interesting by its existence the magical element and belief in it (Zulfadhli,2015, p. 60).

Relating to the beauty of language in literary works includes the beauty of the sounds, words, phrases and arrays. This is stated by Idris, Muhammad Darwis, Mustafa Makka (2012, p. 3) that the linguistic aesthetics of the mantra is a form of beauty radiated through the interweaving of words, lines and stanzas and rhythms). This study focuses on observing the beauty of sounds and words in treatment spells. The consideration is the beauty of sound and beauty of the word is an important component in building the beauty of poetry. Another statement closely related to the previous statement, that the poem is beautiful and useful (Wellek and Warren, 1990, p. 25). Various opinions can be drawn outline, that literature in addition to having beauty also has its own benefits for its readers, so it can be a means of meditation. This is what the writer wants to find in the Mantra Melayu Riau community. Mantra in Riau Melayu society can be grouped into three namely treatment, personal protector and penunduk. This particular study limits on treatment spells. The observed is the aesthetics of language in the Malay treatment of Riau mantra which is limited to the aspect of sound and word.

\section{METHODS}

This is a qualitative research with ethnography method (Spradley, 1997, p. 123). Data collection techniques used observation, interviews and document studies. According to Sugiyono (2008, p. 83) document study is a complement of the use of methods of observation and interviews in qualitative research. The object of research in the form of mantra of Malay Medical Treatment amounted to 59 texts of mantra in the book entitled Mantra. the Data analysis technique used in this research is similar to Miles and Huberman theory (1992, p. 16-17) giving data analysis technique in three stages known as flow model that qualitative data analysis consists of three steps, namely data reduction, data presentation, and withdrawal final conclusion. 


\title{
III. FINDING AND DISCUSSION
}

Essentially, the aesthetic sounds and words in poetry can be found at the beginning of the verse, the center of the verse, the end of the verse and in the array (line). In the aspect of the sound of the smallest level is the similarity of letters. In essence, observers always observe the final patterned font sounds and can build aesthetics like patterned (aa$\mathrm{aa})$, crossed ( $a b-a b)$, hugging ( $a b-b a)$, and twin (aa-bb). The final sound becomes a consideration in building aesthetic sounds in poetry. In addition, also found sound patterns that may be found at the beginning of the word, the end of the word, the similarity of vocal usage (asonansi) and the similarity of consonant use (dissonance). In addition, beauty at the sound level is also known as the arrangement of live sounds (efoni) and dead sounds (kakafoni) and sometimes there is a sound reproduction that represents an object or situation (anomatope).

The beauty aspect of the word is a proper diction process (word choice). The process of diction is done by considering the presence of the word in building aesthetic sounds and accuracy in concealing the meaning to convey the feeling. Because the word sometimes has another word, synonym or similarity of meaning. The author discovers the similarity of sounds and words to the middle and end of the beginning pattern as follows

\section{The Initial Sound}

The initial sound of one example is in the eye sore eye remedy from speakers of Rakin Jamari from Pekanbaru. There are similar initial sounds of the mantra spoken. This becomes an invention of the initial sound pattern as follows.

$$
\begin{aligned}
& \text { Wa ayyuba idz nadaa rabbuhu innii massaniyadhdhurru } \\
& \text { Wa anta arhama rahimin } \\
& \text { Allahumma isyafii ramadan birahmatika yaa arhama rahimin }
\end{aligned}
$$

The aesthetics of this mantra are at the beginning of $\boldsymbol{W a}$ ayyuba with $\boldsymbol{W a}$ anta. The similarity of the array to the initial sound at the syllable level gives the sounding appeal of the rhythm thus giving rise to its own aesthetic present in this mantra. The similarity is to emphasize meaning and in Arabic as a connector with conjunctions like and. Repetition or similarity is included in the aesthetic sounds in literary theory. Repetition as a form of beauty that is in the mantra. Rhythm, sound clash, low height, short length, loud weakness, which flows regularly and repeatedly to form beauty.

\section{Middle Sound}

This spell usually uses turmeric, then turmeric is halved. After that put on hand while reading this mantra. After this spell is read, then turn your palms and turmeric lying on the floor. If ketegoran, then turmeric was applied to the forehead (forehead) as much as 3 times.

\author{
Bismillahirrohmaanirrohim \\ Astagfirullahal'azim $3 X$ \\ Gamit si gelamit tesangkot di gulang-gulang \\ Waktu setan menggamit disitu juge semangat...pulang \\ Janga engkau berduste hal kunyit \\ Durhake engkau kepada Allah \\ Durhake engkau kepada Nabi \\ Durhake engkau kepada aku \\ Asal engkau dari tanah \\ Kembali engkau dari tanah
}

The aesthetics of the mantra are in the middle sound between the Bismillahirrohmaanirrohim sentence in the first line with the Astagfirullahal'azim sentence in the second line. The similarity of llah sounds that rhythmically coincides in different sentences.

\section{Ending Sound}

This mantra is a spell of eye pain that is spoken by Nek Siat from Simandolak. This spell is often used from when the eyes are flushed even to watery. This became the tradition of our grandmother or parents used to treat eye disease. This is stated by by (Yatim et al, 2011, p. 74) Malay-Islamic intellectual culture is driven by the group of ulamak, parents and spear community.

\author{
Bismillahirrohmanirrohim \\ Titiak sakutitiak baronti disungai kalito den manawar \\ Mato sianu itu ru sakit masuak sekalian tawar keluar \\ Sekalian biso, karena allah lillahita'ala \\ Barokat iko go mudah-mudahan mato sianu ru bota amin
}


The aesthetics of the mantra are at the end of the sound. The final sound of Titiak sakutitiak gives the same sound. Also in the final sound of the manawar dengan keluar, and the sound of the root biso, iko, mato make this mantra in the same rhyme so that it has its own aesthetic value. It becomes a living habit for some people in the treatment of eye pain. Literature in this case a mantra is never separated from life experience and imagination (Suryaman, 2004, p. 285).

\title{
Initial Word
}

Aesthetics in the first word of one example is on the mantra of a headache medicine by Syarifudin from Kerinci Kanan. This aesthetic is always at the beginning of the word in each array. This can be seen in the following data.

\author{
Bismillahi khairil asmaa' bismillahi rabildazhi was samaa' \\ Bismilahi adhzi izmuhuu barakatun wa syafaa \\ Bismilahi ladhzi bi ya dihisyi syifaa' \\ Bismilahi ladhzi wa da'a bismilahi ladhzii laa yadhuru ma'asmi syai-un \\ Fil ardhi walia fis samaa
}

The word Bismillahi became an identifiable word containing the aesthetic value of the mantra. The existence of the word similarity in this case the repetition at the beginning of the array becomes part of the beauty when the mantra is spoken. This shows an affirmation which in this case refers to the name of the creator of the name of the place pleading for it in the name of God. Each line begins by calling on God's name as a wish fulfillment.

\section{Middle Word}

The aesthetic identified in the middle word is in the bleeding bidding mantra by Mak Yulinar 63 years old from Kampar. This spell has similar words to the middle words in the array of two, three, and four. This can be seen in the following data.

\author{
Bismilahirrohmanirrohim \\ Tulang batomo tulang \\ Ughek batomo ughek \\ Dagiang batomo dagiang \\ Darah batomo darah \\ Tomun Allah, tomun Muhammad \\ Tomun bagindo Rasululah \\ Tawar Allah, tawar Muhammad \\ Tawar Bagindo Rasulullah berkat Laa ilaaha illallah
}

The word batomo becomes an identifiable word into the aesthetic element in the mantra. The repetition of the word batomo in the mantra up to four times indicates the utmost hope by the speaker of the word. The word represents the imagination of the human body of the bone meeting the bones, the veins meet the tendons, the flesh meets the flesh, and the blood meets the whole blood that is interconnected with each other. The repetition of the word creates its own beauty when the mantra is spoken. it would be unattractive if there were no similarity of words such as words repeated in the mantra of this research data.

\section{Ending Word}

The aesthetics that are identified in the last part of the word are in the mantra of curing a stomachache. This data can be obtained from Mrs. Marni 56 years from Panam, Riau. this spell there is aesthetics that exist in the final word of each line contains aesthetic elements. Here aesthetics are found in the abdominal pain medicine spell.

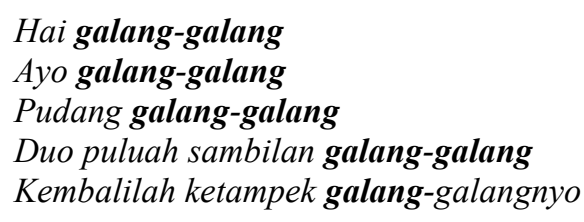

The word galang-galang becomes a word that is identified as an aesthetic element in this mantra. Each array in the spell of the last word is repeated five times. Repetition is the beauty of the mantra when spoken. In addition, said galang-gang likened the sections of the stomach back pain as before as its function. It is an ever-confirmed hope in every array spoken. 


\section{Efoni dan Kakafoni}

The author also found the form of efoni and kakafoni in the Malay treatment spell of Riau as part of the aesthetics of the mantra. It lies in the poison bidder spell obtained from the speakers of Hasnaharah, 53 Years old from the kampar. The following parts of the mantra are identified as part of the aesthetic.

\section{Bismilahirrohmanirrohim \\ Tong tarona rona tacapung tak sa}

The word Bismilahirrohmanirrohim is already known for its heavily synthesized efony elements with the sound of the consonant $\mathrm{m}$ (sound name). Followed by the next line there is the initial affirmation of the dominant caf $\mathrm{t}$ sounds greeted by the sound of vowels and a and o being greeted by the sounds of barrels and tacapung. The two words are mediated by a word that ends with a vowel of torana, hue and not. The meaning of the sound of efoni and kakafoni causes the mantra to aesthetically create matching and rhythmic sounds that radiate beauty for the listener. Especially in the pronunciation of spell the speakers always recite in a half-mumbled way.

The findings from the observation of 59 treatment spells of Malay Riau society found a mantra that has aesthetic elements of sound and words that dominate the text. The mantra is a blood-resistant mantra spoken by Sukri (76) from Kenegerian Kari, Kuantan Singingi.

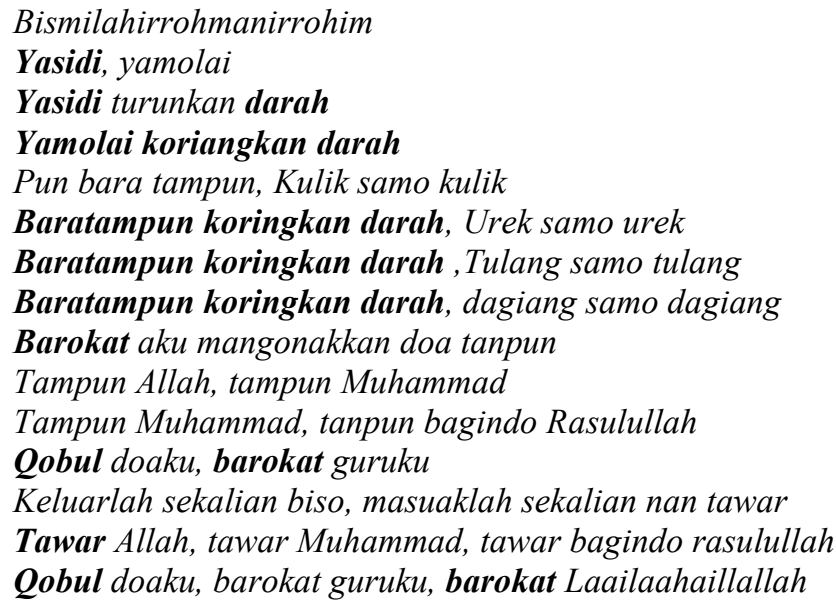

There are repetitions of words at the beginning, in the middle, and at the end of which are combined with similar sounds. Examples of repetition of the word yasidi, baratampun, tampun at the beginning of the stanza added with the same sound as in yasidi said greeted with the word yamolai as well as in western word welcomed with barokat word. That means there are two positions of the similarity of the word with the similarity of sound. It is dominated by the sounds of the efoni (the sound of the orchestra) and occasionally punctuated by the sound of the kakafoni (the sound of whims). This spell from the initial array until the fourth line is dominated by the sound of the efoni. In the fifth and sixth rhythms of the efoni sounds are met with the sound of kakafoni:

\section{Pun bara tampun, Kulik samo kulik \\ Baratampun koringkan darah, Urek samo urek}

First array on the two arrays above Pun bara tampun and baratampun koringkan darah dominated by the sound of the efoni while the second fragment of the sound of kakafoni interspersed with the sound of efoni namely Kulik samo kulik, Urek samo urek. While the final sound pattern can also be found in the middle of the word and the end of the array. The final sound pattern tends to be a twin-shaped pattern such as:

\section{Yasidi turunkan darah \\ Yamolai koriangkan darah}

In the array above the word rhymes down with the word koriangkan because there is a common syllable, while the next word there is a full repetition of the word blood. The similarity of the final sound is found in the array below.

Baratampun koringkan darah ,Tulang samo tulang

Baratampun koringkan darah, dagiang samo dagiang

Aesthetics are represented by similar sounds to the final word of the mantra. the similarity of sound that makes the spell sound more similar and rhythmic. It will be different if there is no similarity of the sound. In addition, the 
author also finds another thing in common with the sound of bone ending and dagiang indicates that this mantra has twin rhymes (aa-aa).

\section{CONCLUSION}

The observation of 59 texts of the treatment spell on the aspect of the sound and the word was found to be the aesthetic of sound to dominate with the result of the initial sound identification of 63 , the central sound of 101, and the final sound of 75 and the initial word amounted to 48, the middle word numbered 51, the end is 27 . The repetition of sounds and words in the mantra sounds similar or rhythmic, giving rise to a beautiful tone that is part of a literary aesthetic. This beauty is a form of affirmation and giving of emotion from speakers through aesthetic mantras conveyed through the aesthetic sounds and words that exist in each mantra. The beauty of sound in the Malay spell adds aesthetic elements to the aspect of pronunciation and diction. The same pronunciation on each contents of the mantra is considered to have a firm effect and influence on the patient. If it is related to the everyday context, the affirmation of words becomes an important thing, since the word is always related to meaning. Language is strongly related to the contexts of where and for what it is used (Risdaneva, 2018, p. 127). Every act of speech is always adjacent to the meaning as a message to the other person. The effect of affirmation and repetition is also expected to give good suggestion in the effort of healing the disease. The authors suggest that this research is not on the aesthetic aspect of sound alone, it is expected to be continued on the deeper aspects, among others, to the social realm or the element of the literary symbol in the mantra.

\section{References}

Agus, A. Bakhtaruddin Nst., \& M. Ismail Nst. (2013). Oral Literature Mantra Treatment In Kenagarian Talu Kecamatan Talamau Pasaman Barat Regency. Unpublished Thesis State University Of Padang.

Dita, S N. (2010). A stylistic analysis of Montage. Journal 3L The Southeast Asian Journal of English Language Studies. 16 (2), p. 169-191.

Idris, M. Darwis, M. Makka. 2012. Characteristic Linguistic Form Mantra: The Stylistic Study. Unpublished Master's Thesis. Hasanudin University.

Miles, B. Mathew \& M Huberman. (1992). Qualitative Data Analysis. Jakarta: UIP.

Risdaneva, (2018). A Critical Discourse Analysis of Women's Portrayal in News Reporting of Sexual Violence. Journal Studies In English Language And Education, 5(1), p. 126-136.

Spradley, J P. (1997). Methods Etnografi.(Translater: Misbah Zulfah Elizabeth,) Yogyakarta: PT Tiara Wacana.

Sugiyono. (2008). Qualitative Quantitative Research Methods and $R \& D$. Bandung: Alfabeta.

Suryaman, M. (2004). Literature Value In Novel People Project Works Ahmad Tohari. Litera, Journal of Language, Literature, and Teaching. Vol. III, No. 2, Juli 2004.

Syafrial., H Rumadi., Elmustian. (2018). Mantra. Pekanbaru: Azizah Publishing.

Waluyo, H J. (1991). Theory and Appreciation of Poetry. Jakarta: Erlangga.

Wellek, R, \& Warren, A. (1990). Literary Theory. Translated Theory of Litterature by Melani Budianta. Jakarta: Gramedia.

Yatim, OMD dkk. (2011). The Malay-Islamic Intellectual Tradition: Instead of Metaphor to Scientificism. Jurnal Melayu UKM. Vol. 6, p. 73-85.

Zulfadhli. (2010). Mantra in Minangkabau Literature and Poetry Sutardji Calzoum Bachri: An Analysis of Comparative Literature . Composition: Journal of Language Education, Literature and Art.. 10 (1), p. 60-67. 